
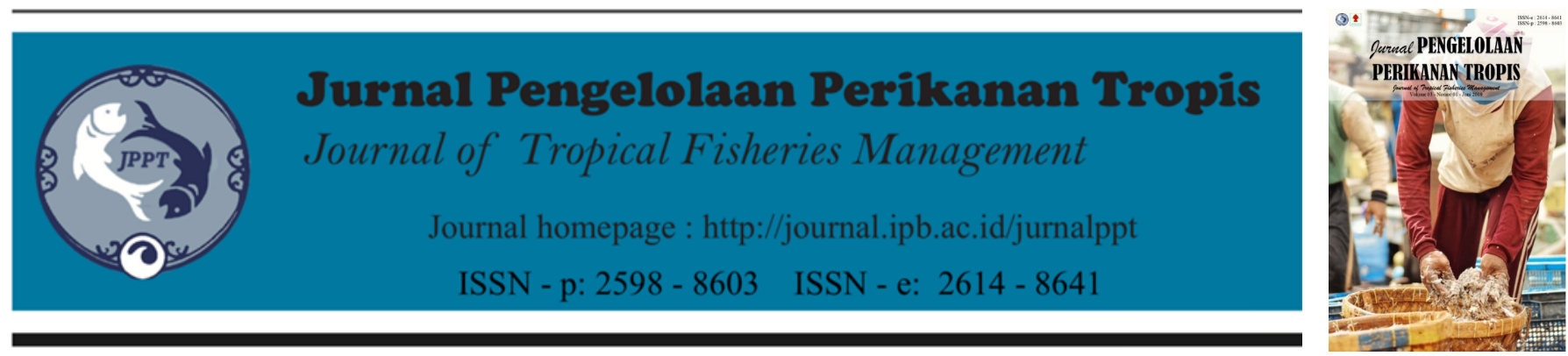

\title{
Indikator Stok Ikan Kembung (Rastrelliger kanagurta Cuvier, 1816) dan Suhu Perairan Selat Sunda
}

\author{
Stock Indicator of Indian Mackerel (Rastrelliger kanagurta Cuvier, 1816) and Temperature \\ in Sunda Strait Waters
}

\section{Zaiinal Arifin Lubis*, Yonvitner, Achmad Fahrudin}

Department Manajemen Sumberdaya Perairan, Fakultas Perikanan dan Ilmu Kelautan, Institut Pertanian Bogor. Jl. Agatis, Kampus IPB Dramaga, Bogor, Jawa Barat, Indonesia.

\begin{tabular}{l}
\hline ARTIKEL INFO \\
\hline Article History \\
Recevied: 1 Maret 2019 \\
Accepted: 28 Mei 2019 \\
\\
\hline Kata Kunci: \\
ikan kembung, laju eksploitasi, \\
parameter populasi, Selat \\
Sunda
\end{tabular}

\section{Korespondensi Author}

Zaiinal Arifin Lubis,

Department Manajemen

Sumberdaya Perairan, Fakultas

Perikanan dan Ilmu Kelautan,

Institut Pertanian Bogor. Email:

zainalarifinlubis43@gmail.cm

\section{ABSTRAK}

Ikan kembung merupakan salah satu hasil tangkapan perikanan Selat Sunda yang memiliki nilai ekonomis penting. Penelitian ini dilakukan untuk menganalisis beberapa parameter populasi dan status stok Kembung (Rastrelliger kanagurta) di Selat Sunda berdasarkan aspek dinamika populasi. Analisis data yaitu atas ukuran pertama kali matang gonad dan tertangkap, mortalitas, laju eksploitasi, model produksi surplus serta fishing ground. Ukuran pertama kali matang gonad ikan kembung adalah 197,2 mm pada jantan dan 177,69 $\mathrm{mm}$ pada betina. Mortalitas penangkapan jauh lebih besar dari mortalitas alami dan laju eksploitasi melebihi 0,5 yang mengindikasikan ikan kembung di Selat Sunda telah mengalami eksploitasi berlebih. Hasil tangkapan maksimum lestari dan upaya optimum adalah 16359,8 ton per tahun dan upaya 129219 trip per tahun. Dalam kaitanya dengan suhu terlihat pola terjadinya penurunan tangkapan pada saat suhu diatas $30^{\circ} \mathrm{C}$. Indikator populasi menunjukkan bahwa ikan kembung di Selat Sunda telah mengalami eksploitasi berlebih. Hal penting yang perlu diperhatikan dalam kaitanya dengan suhu yaitu dinamika tangkapan dengan pola peningkatan suhu yang terus terjadi.

\section{PENDAHULUAN}

Ikan kembung merupakan salah satu ikan pelagis kecil yang sangat potensial dan ditemukan hampir di seluruh perairan Indonesia. Ikan ini berperan penting dalam rantai makanan sebagai pemakan plankton kasar dan hidup secara bergerombol besar di perairan pantai (Genisa 1999). Sumberdaya ikan bagi kebutuhan manusia penting untuk pemenuhan gizi maupun kegiatan perekonomian, mendorong manusia untuk mengeksploitasi sumberdaya ikan sebanyakbanyaknya, termasuk ikan kembung.

Ikan kembung di Selat Sunda cukup potensial dan pertumbuhan produksinya mengalami perkembangan yang berarti. Hal ini tercermin dari hasil tangkapan maupun alat tangkap yang dipergunakan cenderung meningkat. Dengan demikian, kegiatan penangkapan yang dilakukan juga dapat mempengaruhi status stok sumberdaya ikan kembung terutama di perairan Selat Sunda. Kondisi ini tentu juga dapat dipengaruhi oleh kondisi lingkungan dan iklim dengan indikator utamanya adalah suhu. Variasi iklim di Selat Sunda dan sekitarnya yang dapat mempengaruhi ketersediaan sumberdaya sehingga menyebabkan terjadinya fluktuasi produksi.

Perubahan suhu yang terjadi secara umum dapat diduga turut mempengaruhi terjadinya fluktuasi perkembangan populasi mulai dari pertumbuhan sampai reproduksi. Sehingga penting untuk menginternalisasi suhu dan variabel iklim dalam kajian ini. Karena cepat atau lambat proses adaptasi akan terjadi terus sehingga penting selalu diintegrasikan dalam penilaian usaha perikanan.

Kondisi ini yang mendorong perlunya pengkajian dinamika stok dan upaya pengelolaan terhadap sumberdaya ikan kembung di perairan Selat Sunda. Selanjutnya maka usaha perikanan harus dilakukan secara rasional dan bertanggung jawab, yaitu tidak melebihi potensi lestari, tidak merusak lingkungan, serta memperbaiki kembali lingkungan yang rusak akibat dari usaha 
penangkapan yang dilakukan sehingga diperoleh usaha perikanan ikan kembung yang berkelanjutan. Penelitian ini bertujuan menganalisis stok ikan kembung di Selat Sunda sebagai acuan dalam pengelolalaan perikanan berkelanjutan.

\section{METODE}

Penelitian dilaksanakan di Pelabuhan Perikanan Pantai (PPP) Labuan, Banten selama lima bulan yaitu dari bulan Mei sampai September 2018. Pengumpulan data meliputi data panjang, berat, produksi nelayan yang tercatat di PPI Labuan. Contoh ikan yang dikumpulkan mencakup ikan ukuran kecil, sedang dan besar dari jenis ikan yang didaratkan. Selanjutnya data juga dikumpulkan data biologi ikan yaitu kematangan gonad ikan yang dilakukan dilaboratorium Biologi Perikanan Fakultas Perikanan dan Kelautan. Lokasi penelitian dilapangan seperti ditampilkan pada Gambar 1.

\section{Analisis Data}

\section{Ukuran pertama kali matang gonad}

Ukuran pertama kali matang gonad $\left(\mathrm{L}_{\mathrm{m}}\right)$ dapat ditentukan menggunakan sebaran frekuensi proporsi gonad yang telah matang yaitu TKG III dan TKG IV (King 1995). Metode yang digunakan untuk menduga ukuran rata-rata ikan kembung yang pertama kali matang gonad adalah metode Spearman-Karber (Udupa 1986) adalah sebagai berikut.

$$
\mathrm{m}=\left[\mathrm{xk}+\left(\frac{\mathrm{x}}{2}\right)\right]-\left(\mathrm{x} \sum \mathrm{p}_{\mathrm{i}}\right)
$$

Dengan

$\mathrm{M}=\operatorname{antilog} \mathrm{m}$ dan selang kepercayaan $95 \%$ bagi log m dibatasi sebagai

$$
\operatorname{antilog}\left(m \pm 1,96 \sqrt{x^{2} \sum \frac{p_{i} \times q_{i}}{n_{i}-1}}\right)
$$

$\mathrm{m}$ adalah log panjang ikan pada kematangan gonad pertama, xk adalah log nilai tengah kelas panjang yang terakhir ikan telah matang gonad, $\mathrm{x}$ adalah log pertambahan panjang pada nilai tengah, $p_{i}$ adalah proporsi ikan matang gonad pada kelas panjang ke-i dengan jumlah ikan pada selang panjang ke-i, $\mathrm{n}_{\mathrm{i}}$ adalah jumlah ikan pada kelas panjang ke-i, $\mathrm{q}_{\mathrm{i}}$ adalah $1-\mathrm{p}_{\mathrm{i}}$, dan $\mathrm{M}$ adalah panjang ikan pertama kali matang gonad.

\section{Ukuran rata-rata ikan tertangkap}

Ukuran rata-rata ikan tertangkap didapatkan dengan cara memplotkan frekuensi kumulatif dengan setiap panjang ikan, sehingga akan diperoleh kurva logistik baku, dimana titik potong antara kurva dengan 50\% frekuensi kumulatif adalah panjang saat $50 \%$ ikan tertangkap. Nilai length at first capture yaitu panjang pada 50\% pertama kali tertangkap dihitung dengan persamaan sebagai berikut (Sparre dan Venema 1999),

$$
\mathrm{S}_{\mathrm{L}} \operatorname{est}=\frac{1}{1+\exp \left(\mathrm{S}_{1}-\mathrm{S}_{2} * \mathrm{~L}\right)}
$$

SL adalah nilai estimasi, L adalah nilai tengah panjang kelas, S1 dan S2 adalah konstanta.

$$
L c=-\frac{a}{b}
$$

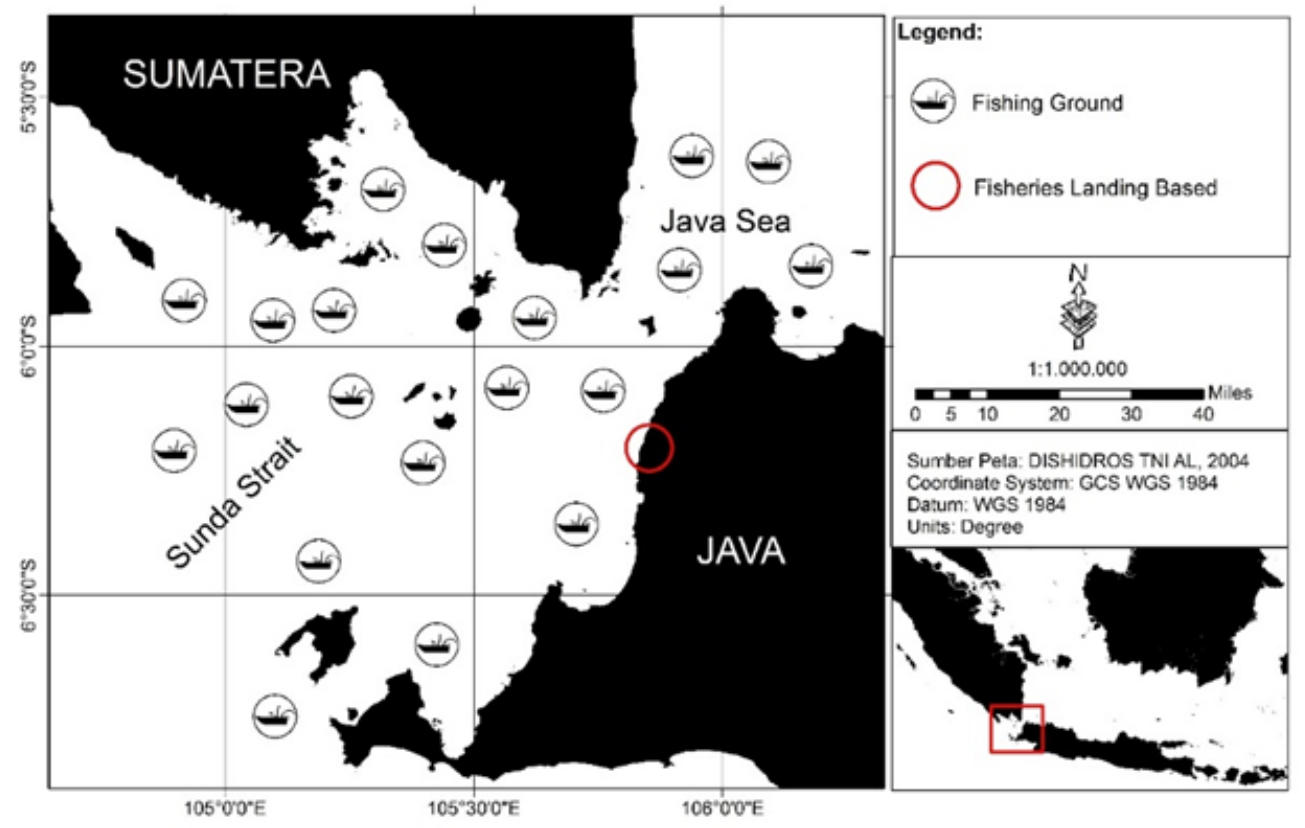

Gambar 1 Lokasi penelitian di perairan Selat Sunda 
Lc adalah panjang ikan pertama kali tertangkap, a adalah S1 dan $b$ adalah S2. a dan b adalah konstanta.

\section{Mortalitas dan laju eksploitasi}

Laju mortalitas total (Z) didapatkan dari jumlah laju mortalitas penangkapan (F) dan laju mortalitas alami yang diduga dengan kurva tangkapan yang dilinearkan berdasarkan data komposisi panjang. Persamaan diduga melalui persamaan regresi linear sederhana $\mathrm{y}=\mathrm{b} 0+\mathrm{b} 1 \mathrm{x}$ dengan:

$$
y=\operatorname{In} \frac{\mathrm{c}\left(\mathrm{L}_{-}-\mathrm{L}_{2}\right)}{\mathrm{An}\left(\mathrm{L}_{\|}-\mathrm{L}_{2}\right)}=\mathrm{C}-\mathrm{Z}^{*} \mathrm{t} \frac{\left(\mathrm{L}_{\mathrm{N}}-\mathrm{L}_{2}\right)}{2}
$$

Laju mortalitas alami (M) diduga dengan menggunakan rumus empiris (Pauly 1980) sebagai berikut :

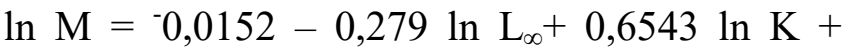
$0,463 \ln \mathrm{T}$

$\mathrm{M}$ adalah mortalitas alami, $\mathrm{L}_{\infty}$ adalah panjang asimtotik persamaan pertumbuhan von Bertalanffy $(\mathrm{mm}), \quad \mathrm{K}$ adalah koefisien pertumbuhan persamaan pertumbuhan von Bertalanffy, $t_{0}$ adalah umur ikan pada saat panjang 0 , dan $\mathrm{T}$ adalah rata-rata suhu permukaan air $\left({ }^{\circ} \mathrm{C}\right)$.

Pauly (1980), menyarankan untuk memperhitungkan jenis ikan yang memiliki kebiasaan menggerombol ikan dikalikan dengan nilai 0,8 sehingga untuk spesies yang menggerombol seperti ikan kembung nilai dugaan menjadi $20 \%$ lebih rendah. Berdasarkan hal tersebut, rumus mortalitas disajikan sebagai berikut.

\section{$\mathrm{M}=0,8 * \mathrm{e}^{\left(-0,0152-0,270 * \ln \mathrm{L}_{\infty}+0,6543 * \ln \mathrm{K}+0,463 * \ln \mathrm{T}\right)}$}

Laju eksploitasi (E) ditentukan dengan membandingkan laju mortalitas penangkapan (F) dengan laju mortalitas total (Z) (Pauly 1980) :

$$
\mathrm{E}=\frac{\mathrm{F}}{\mathrm{F}+\mathrm{M}}=\frac{\mathrm{F}}{\mathrm{Z}}
$$

$\mathrm{M}$ adalah Laju mortalitas alami, $\mathrm{F}$ adalah Laju mortalitas penangkapan, dan $\mathrm{Z}$ adalah Mortalitas total.

\section{Potensi maksimum lestari}

Potensi lestari ikan kembung dapat diduga dengan model produksi surplus berdasarkan data hasil tangkapan (catch) dan upaya penangkapan (effort). Model ini dikembangkan oleh Schaefer dan Fox. Model produksi surplus dapat diterapkan apabila diketahui dengan baik hasil tangkapan per unit upaya tangkap (CPUE) atau berdasarkan spesies dan upaya penangkapannya dalam beberapa tahun. Pendugaan potensi lestari memerlukan standardisasi alat tangkap guna menyeragamkan upaya penangkapan yang ada agar dapat diasumsikan upaya penangkapan suatu alat tangkap dapat menghasilkan tangkapan yang relatif sama dengan alat tangkap yang dijadikan standar (Sharif 2009).

\section{Fishing ground}

Daerah perairan yang menjadi sasaran penangkapan ikan tertangkap dalam jumlah yang maksimal dan alat tangkap dapat dioperasikan serta ekonomis. Analisis Fishing ground melibatkan suhu permukaan laut yang memiliki pengaruh terhadap klorofil $a$ yang mengindikasikan daerah ikan mencari makan atau berkumpul. Titik penangkapan akan dikaitkan dengan sebaran suhu permukaan laut yang dapat menduga keberadaan ikan .

\section{HASIL DAN PEMBAHASAN}

\section{Ukuran pertama kali matang gonad $\left(\mathrm{L}_{\mathrm{m}}\right)$ dan} ukuran pertama kali tertangkap $\left(\mathbf{L}_{c}\right)$

Ukuran pertama kali tertangkap ikan kembung jantan dan betina lebih kecil daripada ukuran pertama kali matang gonad. Hal tersebut mengindikasikan bahwa ikan kembung yang tertangkap merupakan ikan kembung yang belum bereproduksi. Penentuan panjang ikan pertama kali matang gonad dilakukan berdasarkan sebaran frekuensi proporsi gonad yang telah matang (Permatachani 2014). Ukuran pertama kali matang gonad ikan kembung jantan dan betina masing-masing pada Gambar 2 dan Gambar 3.

\section{Mortalitas dan eksploitasi}

Mortalitas pada suatu populasi dapat disebablan oleh faktor alami (M) dan faktor penangkapan $(\mathrm{F})$. Mortalitas total $(\mathrm{Z})$ merupakan jumlah dari mortalitas alami ditambah mortalitas penangkapan. Berdasarkan analisis, mortalitas ikan kembung di Selat Sunda dominan disebabkan oleh aktivitas penangkapan. Laju ekploitasi ikan kembung di Selat Sunda telah melebihi laju optimum. Nilai mortalitas dan laju eksploitasi ikan kembung jantan dan betina disajikan pada Tabel 1.

\section{Model produksi surplus}

Ikan kembung merupakan ikan yang ditangkap menggunakan berbagai jenis alat tangkap. Berdasarkan hasil analisis perhitungan, diperoleh hasil bahwa alat tangkap yang produktif untuk menangkap ikan kembung adalah dogol, payang dan pukat cincin yang menggunakan kapal motor dengan hasil tangkapan tertinggi yaitu 24312,1 ton dan upaya maksimal sebesar 275212,96 trip. Hubungan hasil tangkapan 


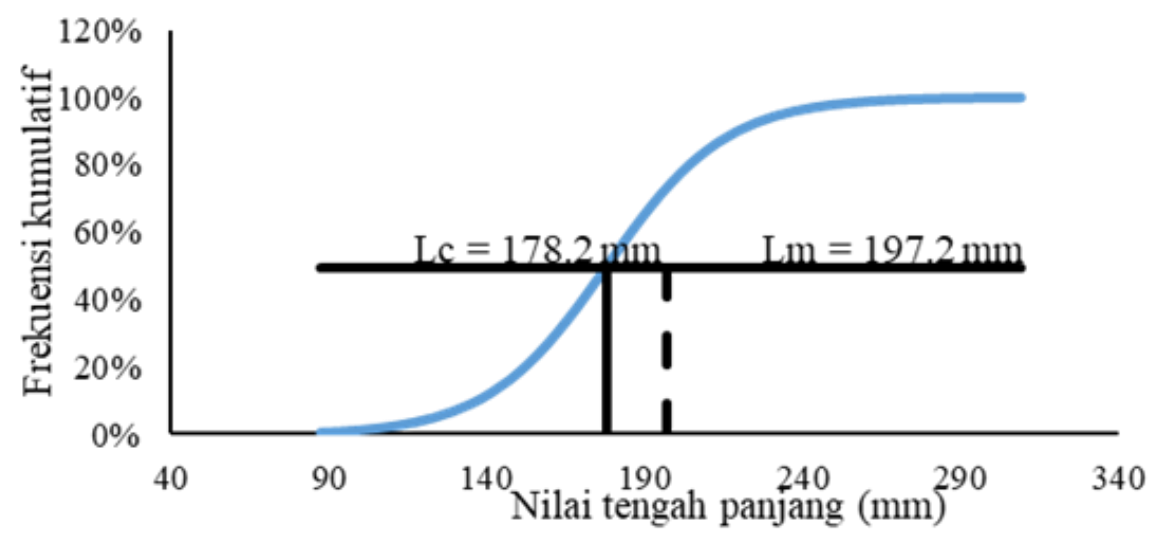

Gambar 2 Panjang pertama kali matang gonad dan tertangkap ikan kembung (Rastrelliger kanagurta) jantan

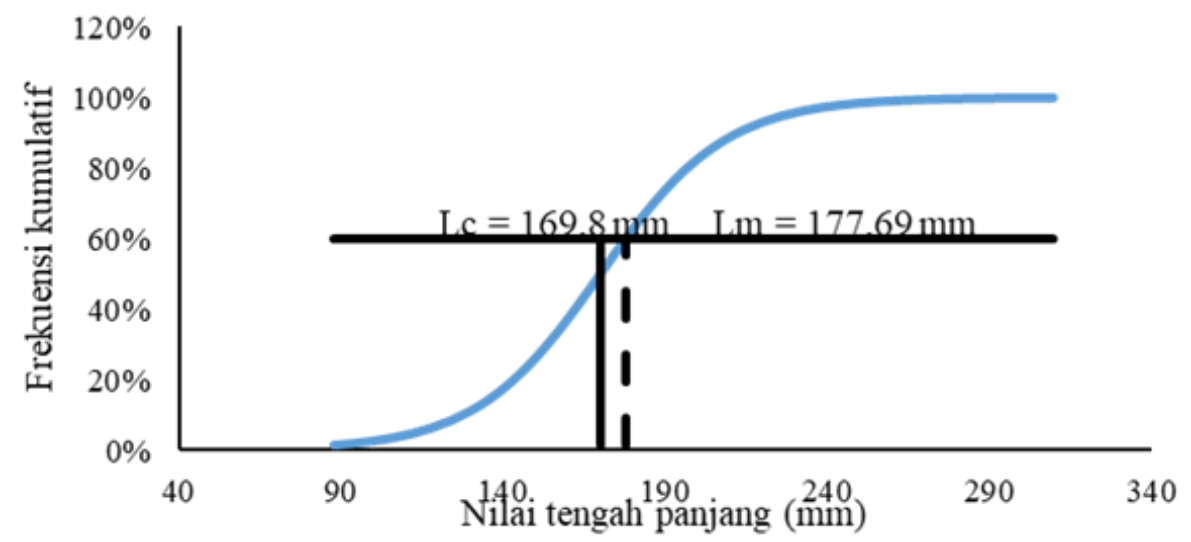

Gambar 3 Panjang pertama kali matang gonad dan tertangkap ikan kembung (Rastrelliger kanagurta) betina

Tabel 1 Mortalitas dan laju eksploitasi ikan kembung (Rastrelliger kanagurta)

\begin{tabular}{lll}
\hline \multirow{2}{*}{ Parameter } & \multicolumn{2}{c}{ Nilai (per tahun) } \\
\cline { 2 - 3 } & Jantan & Betina \\
\hline Mortalitas total $(\mathrm{Z})$ & 3,3962 & 1,4767 \\
\hline Mortalitas alami $(\mathrm{M})$ & 0,7750 & 0,4988 \\
\hline Mortalitas penangkapan $(\mathrm{F})$ & 2,6212 & 0,9778 \\
\hline Eksploitasi (E) & 0,7718 & 0,6622 \\
\hline
\end{tabular}

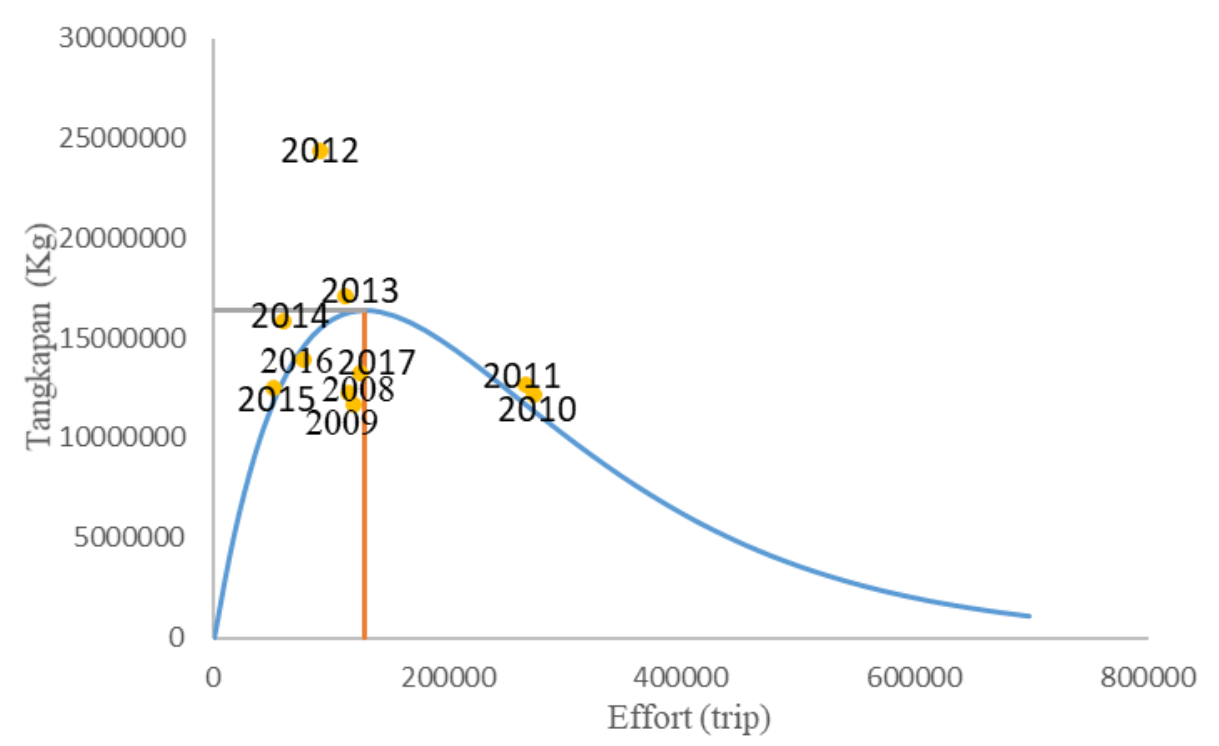

Gambar 4 Potensi lestari ikan kembung (Rastrelliger kanagurta) di Selat Sunda 
yaitu 24312,1 ton dan upaya maksimal sebesar 275212,96 trip. Hubungan hasil tangkapan dengan effort disajikan pada Gambar 3. Berdasarkan analisis diketahui bahwa tangkapan aktual pada tahun 2012 melebihi MSY dan pada tahun 2010, 2011 Effort aktual melebihi FMSY. Hal ini mengindikasikan bahwa ikan kembung di Selat Sunda telah mengalami eksploitasi berlebih.

\section{Fishing ground}

Daerah perairan yang menjadi sasaran penangkapan ikan tertangkap dalam jumlah yang maksimal dan alat tangkap dapat dioperasikan serta ekonomis. Berdasarkan analisis suhu dan hasil tangkapan keberadaan ikan kembung di selat sunda dapat diindikasikan bahwa suhu tinggi menghasilkan tangkapan minimum. Hubugan analisis suhu dan hasil tangkapan di sajikan pada gambar 9 .

\section{Pembahasan}

Berdasarkan analisis pendugaan ukuran pertama kali matang gonad (Lm) diketahui bahwa, ukuran pertama kali matang gonad (Lm) ikan kembung betina lebih kecil dibandingkan ikan kembung jantan. Ukuran pertama kali tertangkap ikan kembung jantan adalah pada ukuran 178,2 mm, sedangkan ukuran pertama kali ikan betina ditangkap adalah adalah pada ukuran 169,8 mm. Hal ini mengasumsikan bahwa sebanyak 50\% ikan kembung di Selat Sunda telah mencapai ukuran matang gonad pada panjang tersebut (Risti 2015).

Ikan yang satu spesies belum tentu mencapai ukuran pertama kali matang gonad pada panjang yang sama. Perbedaan ukuran pertama kali matang gonad antara ikan kembung jantan dan betina dapat disebabkan oleh perbedaan nilai koefisien pertumbuhan. Perbedaan tersebut dapat disebabkan oleh faktor internal dan faktor eksternal. Faktor internal meliputi umur, jenis kelamin, ukuran serta kondisi dan sifat fisiologi ikan, sedangkan faktor eksternal yaitu kebiasaan makan suhu dan arus (Lagler et al.1977 in Larasati 2011).

Ukuran pertama kali tertangkap ikan kembung jantan adalah pada panjang $178,2 \mathrm{~mm}$, sedangkan ukuran pertama kali tertangkap ikan kembung betina adalah pada panjang $169,8 \mathrm{~mm}$. Ukuran pertama kali tertangkap ikan kembung jantan dan betina lebih kecil daripada ukuran pertama kali matang gonad. Hal ini mengindikasikan bahwa sebagian besar ikan kembung yang tertangkap belum melakukan reproduksi untuk menjaga ketersediaan stok di alam. Tertangkapnya ikan kembung yang belum matang gonad disebabkan oleh alat tangkap yang ukuran mata jaringnya kecil atau tidak ramah lingkungan (Dahlan et al. 2015).
Mortalitas total ikan kembung jantan di Selat sunda lebih tinggi daripada mortalitas total ikan kembung betina. Hal ini mengindikasikan bahwa kondisi stok ikan kembung jantan di perairan di Selat Sunda lebih rentan. Mortalitas penangkapan ikan kembung di Selat Sunda menunjukkan nilai yang lebih besar daripada mortalitas alaminya. Berdasarkan hal tersebut diperkirakan kematian ikan kembung di Selat Sunda lebih dominan disebabkan oleh aktivitas penangkapan.

Mortalitas alami disebabkan oleh pemangsaan, umur, penyakit, ketersediaan makanan serta kondisi lingkungan (Sparre dan Venema 1999). Berdasarkan hasil analisis, nilai eksploitasi ikan kembung jantan dan ikan kembung betina lebih besar dari 0,5. Menurut Gulland (1971) in Pauly (1984), apabila laju eksploitasi suatu jenis ikan melebihi nilai optimal $(0,5)$, maka telah terjadi eksploitasi berlebih (overexploited). Apabila tingkat eksploitasi di suatu daerah semakin tinggi, maka tingkat mortalitas penangkapannya semakin besar (Lelono 2007 dalam Syakila 2009).

Alat tangkap yang digunakan untuk menangkap ikan kembung di Selat Sunda, yaitu dogol, payang dan purse seine. Penggunaan model surplus produksi bertujuan untuk meningkatkan upaya optimum (effort MSY atau fmsy), yaitu upaya yang menghasilkan suatu hasil tangkapan yang maksimum lestari tanpa mempengaruhi stok secara jangka panjang atau yang sering disebut Maximum Sustainable Yield/ MSY serta jumlah tangkapan yang diperbolehkan (Sinaga 2010). Jumlah tangkapan yang dianjurkan adalah $80 \%$ dari potensi maksimum lestarinya (Susilo 2009). Hasil analisis menggunakan metode fox diperoleh nilai MSY sebesar 16359,8 ton dan $f_{\text {MSY }}$ sebesar 129219 trip. Pada tahun 2012 jumlah tangkapan melebihi dari MSY. Pada tahun 2010 dan 2011 upaya yang dilakukan melampaui $\mathrm{f}_{\mathrm{MSY}}$.

Berdasarkan nilai MSY dan $\mathrm{f}_{\mathrm{MSY}}$, pemanfaatan terhadap ikan kembung di Selat Sunda telah mengalami laju eksploitasi optimum. Hal tersebut disebabkan karena tingginya aktivitas penangkapan ikan kembung. Upaya pengelolaan dapat dilakukan dengan mencatat dan melakukan pengawasan terhadap kapal penangkap ikan dan terhadap hasil tangkapannya juga. Melakukan pembatasan penangkapan ikan kembung yaitu 16359,8 ton dengan upaya maksimal yang diperbolehkan 129219 trip. Selain itu, selektivitas alat tangkap juga harus diperhatikan agar tidak ada ikan yang belum matang gonad yan tertangkap. Pengelolaan sumberdaya ikan ditentukan oleh cara memanfaatkan sumberdaya yang ada seoptimal mungkin dengan tetap menjaga kelestariannya.

Hubungan hasil tangkapan dengan SPL memiliki pola yang berbeda-beda, suhu lebih dari 


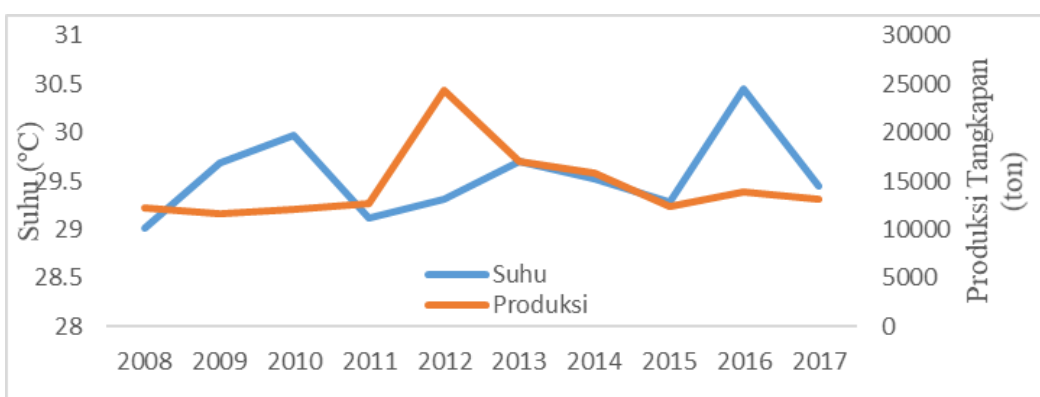

Gambar 4 Suhu permukaan dan produksi ikan kembung (Rastrelliger kanagurta) di Selat Sunda

Hubungan hasil tangkapan dengan SPL memiliki pola yang berbeda-beda, suhu lebih dari $30^{\circ} \mathrm{C}$ mengakibatkan produksi tangkapan yang relatif turun. Hasil tangkapan ikan kembung tidak memiliki pengaruh yang signifikan terhadap naik turunnya SPL. Hal ini mengindikasikan bahwa saat suhu lebih dari $30^{\circ} \mathrm{C}$ ikan kembung akan melakukan imigrasi ke daerah yang sesuai dengan kondisinya. Hasil produksi perikanan tangkap salah satunya dipengaruhi oleh faktor alam. Secara tidak langsung kondisi alam juga dapat mempengaruhi jumlah trip penangkapan dan jumlah titik penangkapan, karena nelayan secara umum akan tergantung oleh cuaca untuk melakukan proses penangkapan dan menentukan lokasi penangkapan (Agus et.al 2013). Makanan juga memiliki pengaruh terhadap keberadaan ikan kembung (Nontji 2005), sehingga pada saat curah hujan tinggi ketersedian makanan dialam akan relatif sedikit.

\section{KESIMPULAN}

Nilai panjang pertama kali tertangkap ikan kembung lebih kecil dari nilai pertama kali matang gonad. Mortalitas penangkapan jauh lebih besar dari mortalitas alami dan laju eksploitasi melebihi 0,5 yang mengindikasikan ikan kembung di Selat Sunda telah mengalami eksploitasi berlebih. Potensi maksimum lestari menunjukan ikan kembung di Selat Sunda telah mengalami eksploitasi berlebih serta terjadinya penurunan tangkapan pada saat suhu diatas $30^{\circ} \mathrm{C}$.

\section{DAFTAR PUSTAKA}

Agus H, Urfan R, Max RM. 2013. Analisa sebaran tangkap ikan lemuru (sardinella lemuru) berdasarkan data satelit suhu perrmukaan laut dan klorofil-a di perairan Selat Bali. Diponegoro Journal of Maquares. 4(2): 53-60

Dahlan MA, Omar SBA, Tresnati J, Umar MT, Nur M. 2015. Nisbah kelamin dan ukuran pertama kali matang gonad ikan layang deles (Decapterus macrosoma Bleeker, 1841) di perairan Teluk Bone, Sulawesi Selatan. Jurnal Ilmu Kelautan dan Perikanan. 25(1) : 25-29.

Genisa AS. 1999. Pengenalan jenis-jenis ikan laut ekonomi penting di Indonesia.
Jurnal Oseana. 1(24):17-38.

King M. 1995. Fisheries Biology, Assessment, and Management. London (GB): Fishing News Books.

King M. 1995. Fisheries Biology, Assessment, and Management. London (GB): Fishing News Books.

Nontji A. 2005. Laut Nusantara. Djambatan. Jakarta

Larasati DA. 2011. Kajian biologi reproduksi ikan kembung perempuan (Rastrelliger brachysoma Bleeker, 1851) di perairan Teluk Jakarta, Jakarta Utara [skripi]. Bogor (ID) : Institut Pertanian Bogor.

Pauly D. 1984. Fish population dynamics in tropical waters: a manual for use with progammable calculators. ICLARM. Manila. Filipina.

Pauly D. 1980. On the interrelationships between natural mortality, growth parameters, and mean enviromental temperature in 175 fish stocks. ICES Journal Marine Science. 39(2): 175-192.

Permatachani A. Boer M, Kamal MM. 2016. Kajian stok ikan peperek (Leiognathus equulus) berdasarkan alat tangkap jaring rampus di Perairan Selat Sunda. Jurnal Teknologi Perikanan dan Kelautan. 7(2): 107 $-116$.

Risti. 2015. Kajian stok sumberdaya ikan layur (Lepturacanthus savala) di Perairan Selat Sunda. [skripsi]. Bogor (ID): Institut Pertanian Bogor.

Sharif A. 2009. Studi dinamika stok ikan layur (Lepturacanthus savala) di Teluk Palabuhanratu, Kabupaten Sukabumi, Propinsi Jawa Barat [skripsi]. Bogor (ID): Institut Pertanian Bogor.

Sparre P, Venema S. 1999. Introduksi Pengkajian Stok Ikan Ttropis Buku Manual. Jakarta (ID): Pusat Penelitian dan Pengembangan Perikanan.

Syakila S. 2009. Studi dinamika stok ikan tembang (sardinella fimbriata) di Perairan Teluk Palabuhanratu, Kabupa ([skripsi]). Bogor (ID): Institut Pertanian Bogor.

Udupa K. 1986. Statistical method of estimazing the size at first maturity of fishes. Fishbyte. 4 (2):8-10. 